\title{
A study on listed companies' compliance with value-added tax: the evolving role of compliance officer in Oman
}

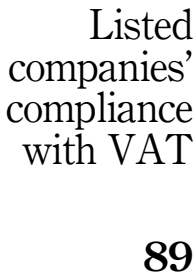

\author{
Mohammed Muneerali Thottoli \\ University of Nizwa, Nizwa, Oman
}

Received 14 March 2021 Revised 9 December 2021 Accepted 16 January 2022

\begin{abstract}
Purpose - The purpose of the paper is to examine current companies' compliance with value-added tax (VAT) and the evolving role of the compliance officer in the listed companies at Muscat Stock Exchange (MSX), Oman. Design/methodology/approach - The study has collected various compliance measures set by Capital Market Authority (CMA) from 2011 to 2019. On top of the websites of CMA, MSX, Oman Tax Authority and other related websites, the paper has considered real data of specific compliance or disclosure measures set by CMA on all companies listed under MSX. The focused period from 2011 to 2019 is where CMA has provided disclosure data as part of mandatory disclosure requirements.

Findings - This paper identified that there is a lack of timely compliance by companies under the existing law, and these companies may face pressures for compliance with VAT enforcement in Oman. Therefore, to comply with the disclosure requirements of listed companies, there is a growing need to appoint a full-time compliance officer and do a compliance audit.

Practical limitations/implications - The results of the study indicate the value of full-time compliance officers and compliance audits. The findings are able to aid in the appraisal of VAT accounting, compliance audit research, and in the selection of proper assessment methods and criteria.

Originality/value - This paper reviews the literature and provides new empirical analysis that are possibly beneficial for both scholars and accounting practitioners.
\end{abstract}

Keywords Companies compliance, VAT compliance, Muscat Stock Exchange, Capital Market Authority, Compliance Officer, Oman

Paper type Research paper

\section{Introduction}

Every organization tries to keep the brand image, standard, and high quality by complying with applicable rules and regulations issued by both internal and government regulations or policies from time to time. All listed companies must comply with different rules, regulations, laws, and guidelines. Implementing timely compliance helps companies to prevent and detect legal violations of laws or rules, which protects organizations from government levies in form of penalties, fine, and lawsuits. Timely compliance avoids loss of stakeholders' selfconfidence and damage of the company's reputation. Likewise, compliance provides efficiency and accountability into the organizational operating system. A full-time compliance officer ensures the compliance of company laws, tax laws, standards, and

(C) Mohammed Muneerali Thottoli. Published in Public Administration and Policy. Published by Emerald Publishing Limited. This article is published under the Creative Commons Attribution (CC BY 4.0) license. Anyone may reproduce, distribute, translate and create derivative works of this article (for both commercial and non-commercial purposes), subject to full attribution to the original publication and authors. The full terms of this license may be seen at http://creativecommons.org/licences/by/4.0/ legalcode

The author would like to acknowledge the journal's Managing Editor, Dr. Alice Y.C. Te, anonymous reviewers, and Mr. Pius Ochieng, IELP Teacher, University of Nizwa, Oman for their critical reading and insightful suggestions/comments, which significantly improved the manuscript's quality.

\section{HKPAA}

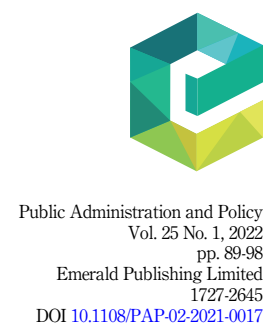


PAP

25,1

other applicable regulations. They can also ensure the compliance with the clauses of Articles of Association, Memorandum of Association, and other related corporate bylaws, policies, and procedures. Compliance officers provide services to listed companies and work independently to identify and oversee the company's regulatory risks.

Compliance may seem complicated and expensive; however, the cost of non-compliance will be greater. Some business expansions will be required by adhering to additional rules. Multinational companies have to comply with more compliance regimes. If any company does not meet industry-specific standards, it will possibly need to pay fines, and consequently affecting the business integrity. Listed companies generally are not ready to appoint a fulltime compliance officer, as it will increase business operational costs. Corporate governance rules are other notable compliance aspects. Failure to comply with corporate governance rules will increase organizational operational risk which may affect the interests of stakeholders (Zerban and Madani, 2018). Generally, in Oman, the non-compliance penalties of both direct tax and indirect tax by companies are very high. Future operational profits will possibly be influenced by non-compliance with tax regulations by levying tax penalties (Tarmidi, 2019). The non-compliance with the latest International Financial Reporting Standards (IFRS) by companies was problematic across companies (Tawiah and Boolaky, 2019).

Compliance related to corporate law and taxation law is less in Gulf Cooperation Council (GCC) countries when compared to non-GCC countries. However, recently as part of GCC countries' economic development, the Omani government has been forced to amend/ implement new regulations under the existing corporate law. Furthermore, the recent introduction of value-added tax (VAT) laws in GCC including Oman has made organizations more compliant than before. With a special focus on Oman, this paper investigates various challenges faced by companies in their implementation of compliance standards. The main purpose of this paper is to examine current companies' compliance with value-added tax (VAT) laws and the evolving role of compliance officers in the listed companies at Muscat Stock Exchange (MSX), Oman.

\section{Literature review}

A compliance officer is mainly responsible for managing and monitoring the statutory and regulatory compliance frameworks of a company. Compliance involves compliance with the law, rules, regulations, policies and standards. Listed companies must follow several regulatory compliances for their successful operations and corporate disclosures. Overseas involvement in company's corporate tax non-compliance and the involvement of foreign Chief Executive Officers on corporate tax non-compliance were examined by Suleiman (2021). The impact of intergovernmental shifts on firms' corporate tax non-compliance was investigated by Ye and Xiang (2020). The rationales about large-scale tax non-compliance in underdeveloped nations' tax administration reforms were studied by Umar and Masud (2020). The factors of compliance disclosure on of IFRS among listed insurance companies were examined by Suleiman and Sani (2021). Arena et al. (2018) investigated broad corporate social responsibility disclosure in Asian countries with the goal of unraveling whether such regulatory disclosures are the effect of proactive views or a response to regulations. Venturelli et al. (2019) studied non-financial information of larger public companies and their disclosure requirements of social, environmental, and governance sectors. Saenz and Brown (2018) aimed to create a tool based on global standards for assessing anti-corruption, noncompliance in various organizations and anti-corruption methods disclosed by companies under the construction sector. Baalouch et al. (2019) studied the effect of several aspects on the quality of environmental disclosure policies. Investor feedback to the companies' disclosure regulations on compliance and non-compliance of taxation provisions was analyzed by 
Tarmidi (2019). The practical effect of using e-filing of tax returns, the use of e-invoicing and levy of administrative fines on individual taxpayer compliance were investigated by Sentanu and Budiartha (2019). The successful compliance by companies listed in the securities market with the country's code's proposals on related-party transactions and minority shareholders interest were analyzed by Maglio et al. (2020).

It is evidenced that the role of a compliance officer will guarantee the effective and efficient management of a firm's compliance risks, prevent their bias, and promote optimization. If an acceptable level of regulatory compliance is proven, organizations at an initial phase go for practical and rational application (Fiandrino et al., 2019). It is found that moral culture, companies' internal control operations, and corporate governance on financial reporting provide a substantial contribution to applicable IFRS compliance for listed companies (Nalukenge et al., 2018). The setting of regulatory compliance functions in any organization is an important factor for compliance demands on any corporations to continue to strive. The growing complexity of finance and regulatory compliance requires integrating the compliance regulatory management functions inside the organization (Usnick et al., 2018). It is found that detection moderates the nexus among interactional fairness and intention of tax compliance diminishes with higher detection (Farrar et al., 2019). It is evident that listed companies are strictly adherent to the laws of anti-corruption and it is also revealed that greater levels of adherence to financial or regulatory compliance programs are linked with higher adoption of internal controls in the organization. A company's own specific characteristics are crucial factors that affect various tax disclosures (Mgammal et al., 2018). It has been found that company secretaries or compliance officers considerably influence financial reporting and board practices because of their positions and roles (Nowland et al., 2020). The separation of compliance responsibility from the legal functionaries of a company might not be advisable as both structures are frequently demanded upon by governors, regulators, and enforcement authorities. Therefore, the role of a compliance officer should be delegated to legal officers so that one officer can solely be charged with interpreting corporate or tax law and advising the company about the legal requirements (Meissner, 2018).

The lack of compliance audit on disclosure guidelines of financial statements increases the risk of disciplinary actions such as fines, penalties, civil and criminal liabilities (Thottoli, 2021). Certain associated risks for regulatory compliance were observed by Van Wyk and Rudman (2019) while entrepreneurial mode strives to establish leaner structure in various parts of the institution. Some listed companies have not been given any legal protection from criminal or civil liability by adopting compliance programs on corporate social responsibility and codes of conduct. Executive officers of organizations who have failed to perform operations in compliance with government implemented policies have been removed from their positions (Pastory, 2019).

Based on the literature regarding the link between companies' compliance (including tax compliance) and the role of the compliance officer in a listed company, this paper has adopted a framework to show the evolving role of a full-time compliance officer. As shown in Figure 1, the management of a company tries to achieve objectives as per internal regulations financial regulations, management, clauses of Memorandum of Association, and clauses of Articles of Association; and external regulations - government including tax authorities, IFRS, securities laws, banking regulations, Islamic sharia rules, and insurance regulations. On the other hand, a full-time compliance officer shall be required to oversee the internal and external regulations in a timely manner.

\section{Research methodology}

The Capital Market Authority (CMA) is responsible to monitor the compliance issuers of securities in Oman. This paper has obtained sourced data from the websites of CMA, Muscat 


\section{PAP \\ 25,1}

\section{2}

Figure 1.

The evolving role of compliance officer

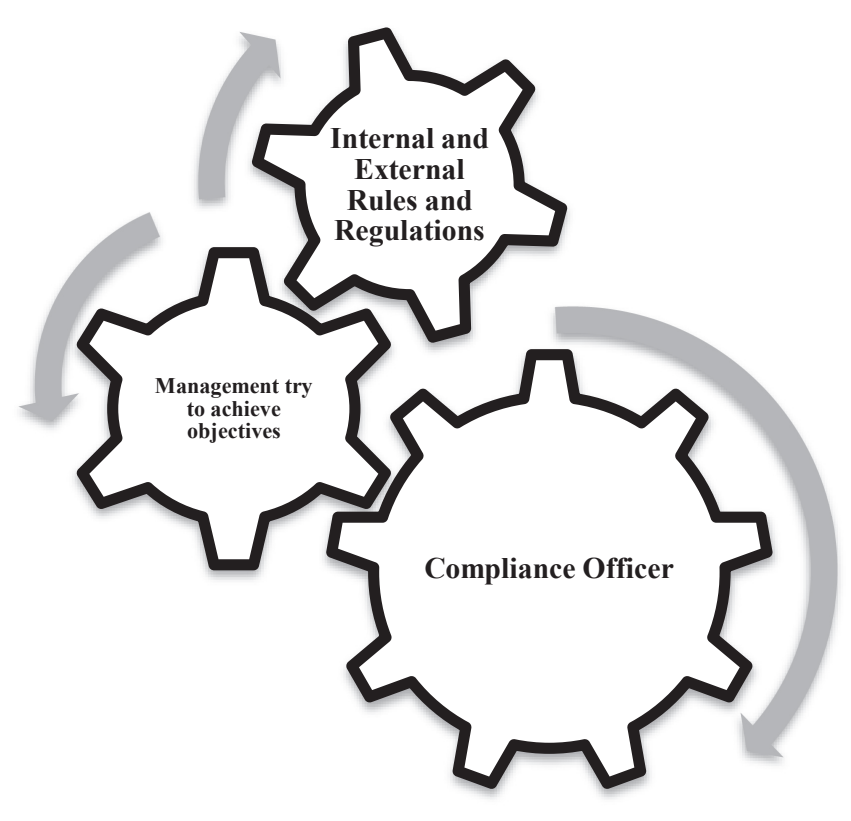

Source: By author.

Stock Exchange, and Oman Tax Authority. Moreover, the paper has considered real data of specific compliance or disclosure measures set by CMA on all companies listed under MSX from 2011 to 2019. The CMA index information consists of both quantitative and qualitative data such as the details of compliant and non-compliant companies with various listed violations/issues, the disciplinary actions taken against them as well as the evaluation criteria followed. In addition, the paper has collected available value-added tax information from the authorized websites of the Oman tax authority and the Government of Oman.

\section{Findings and discussion}

Current companies' compliance of listed companies in Oman

Latest research studies in regulatory, financial, and internal compliance (Majerowska and Spigarska, 2021; Chang et al., 2019; Tawiah and Boolaky, 2019) validate the results of the present study on current companies' compliance of listed companies. The majority of the study revealed that overseeing the compliance of companies with internal regulations is vital for consistent growth and profitability. In Oman, this related study was broadened by Sarea et al. (2020).

Table 1 below indicates descriptive results of the disclosure index reported by CMA and MSX from 2011 to 2019. The main reasons for disciplinary actions were for non-compliance of Executive Regulation of the Capital Market Law, Commercial Companies Law, Insurance Companies Law, Insurance Agents Licensing Requirements, Brokers' Regulation, Clearance and Settlement Regulation, Unified Motor Vehicles Insurance Policy, Auditors Accreditation Rules, International Accounting and Auditing Standards, Auditors Accreditation Rules, and provisions for practicing accounting and auditing professions.

Table 2 indicates descriptive results of the reported disclosure index by CMA from 2011 to 2019. Some companies were found non-compliant with the required statement as per the CMA 
2011 Infringement of Articles 301 of the Executive Regulation of the Capital Market Law

Infringement of Articles 117 and 83 of the Commercial Companies Law and Article 20 of the Executive

Regulation of the Capital Market Law

Infringement of Article 12 of Administrative

2012 Infringement of Articles 279 of the Executive Regulation of the Capital Market Law Infringement of Articles 291 of the Executive Regulation of the Capital Market Law Infringement Clause 1 of Article 157 of the Executive Regulation of the Capital Market Law

2013 Infringement of circular No. (6/2012)

Infringement of article 1/19 of the Insurance company law and articles $8 \& 7$ from the Executive

Regulation of Insurance Companies Law

Total 16 number of, MISCELLANEOUS FORMAL REGULATORY DECISIONS

2014 Infringement of Article 280 of the Executive Regulation of Capital Market Law

Infringement of Article 124 of the of the Executive Regulation of Capital Market Law

Infringement of Decision 26 on obtaining CMA's approval for new insurance products

Infringement of circular No. 6/2012

Total 4 number of, MISCELLANEOUS FORMAL REGULATORY DECISIONS

2015 Infringement of Article 125 of the Executive Regulation of the Capital Market Law and failure to apply

Article 163 of the same regulation

Infringement of Article 9 of the Regulation of the Insurance Companies Law

Infringement of Brokers' Regulation

Infringement of Article 8 of the Regulation of the Insurance Companies Law

Infringement of Article 17 of Brokers' Regulation

Infringement of Article 9 of Brokers' Regulation

Infringement of Clause 7 of Article 11 of Brokers' Regulation and clauses 1 and 2 of Article 13

Infringement of Clause 14 of the Code of Professional Conduct and Article 3 of Insurance Agents

Licensing Requirements

Total 4 number of, MISCELLANEOUS FORMAL REGULATORY DECISIONS

2016 Violation of the provision of Article 147 of ERCML

Violation of the last para of Article 54 of ERCML

Violation of Article 12 of AD 6/2002 on constitution of internal audit committee and appointment of legal advisor

Violation of Article 311 of ERCML

Violation of Clause 3 of Article 55 of Clearance and Settlement Regulation

2017 Violation of the provisions of Article 280 of the Executive Regulation of the Capital Market Law relating to disclosure of the initial results of the first quarter

Violation of the provisions for practicing accounting and audit profession

Violation of the provisions of Unified Motor Vehicles Insurance Policy

Violation of the provisions of Article 1 of Ministerial Decision No. 26/86 and Article 3 of Insurance Agents

Licensing Requirements

Violation of Article 9 of Insurance Agents Licensing Requirements

2018 Violation of the provisions of Article 146 of the Executive Regulation of the Capital Market Law

Violation of Clause (b) of the provisions of Article 123 of the Executive Regulation of the Capital Market

Law

Violation Article 5 of the Capital Market Law

Violation Article 149 of the Executive Regulation of the Capital Market Law

Violating certain international accounting and auditing standards

Violating Articles 112 and 113 of the Commercial Companies Law

Violation of Schedule (b) of the Unified Motor Insurance Policy

Violation of the provisions of Article 12/4 of Insurance Agents Licensing Requirements

Violating Articles 112 and 113 of the Commercial Companies Law, Article 5 of the Capital Market Law and article 282 of the Executive Regulation of the Capital Market Law

Violation of the provisions of Article 20 of Insurance Brokers Regulation

2019 Violation of the provisions of Insurance brokerage regulation

Violation of the clause of standard motor insurance policy

Failure to remedy the situation as per the resolution of the BOD of CMA

Violating second paragraph of Article (1) of the Auditors Accreditation Rules

Source: CMA Annual Reports adapted from Capital Market Authority (2011-2019).

Table 1.

Disciplinary reasons 
PAP

25,1

\section{4}

Table 2.

Non-compliance of 'required statements' by companies (2011-2019) disclosure index. Major discrepancies were found on required statements such as: unaudited annual results, audited annual financial statements, first-quarter financial statements, second-quarter financial statements, third-quarter financial statements, dissemination of audited annual financial statements, disclosure of the resolutions of the general meetings, and timely material information.

Table 3 indicates descriptive results of the reported disclosure index by CMA from 2011 to 2019. Some companies were found to be non-compliant with several directors' meetings, noncompliance with directors' roles, non-compliance with audit committee's role, non-compliance with rules for appointment of auditors, non-compliance with executive management's role, non-compliance with minimum internal regulations, violation information of audit committee, violation in the appointment of an internal auditor and legal advisor, noncompliance of internal auditor's work and role, non-compliance of internal auditor in preparing annual work plan before the year, non-compliance in the appointment of secretary to the board, non-compliance in legal advisor's role, non-compliance with Articles of Association of the company, and non-compliance with executive regulation.

\section{Value-added tax compliance on listed companies}

The Tax Authority of Oman issued three executive decisions on the implementation of the value-added tax, which entered the enforcement stage by April 16, 2021. Research studies in

\begin{tabular}{ll}
\hline Number & Required Statements \\
\hline 1 & Unaudited annual results \\
2 & Audited annual financial statements \\
3 & First quarter financial statements \\
4 & Second quarter financial statements \\
5 & Third quarter financial statements \\
6 & Dissemination of audited annual financial statements \\
7 & Disclosure of the resolutions of the general meeting \\
8 & Timely material information
\end{tabular}

Source: Adapted from Capital Market Authority (2011-2019).

\begin{tabular}{ll}
\hline Number & Type of violation \\
\hline 1 & Non-compliance with number of Directors' meetings \\
2 & Non-compliance with Directors' roles \\
3 & Non-compliance with audit committee's role \\
4 & Non-compliance with rules for appointment of auditors \\
5 & Non-compliance with executive management's role \\
6 & Non-compliance with minimum internal regulations \\
7 & Violation in formation of audit committee \\
8 & Violation in appointment of internal auditor and legal advisor \\
9 & Non-compliance of internal auditor's work and role \\
10 & Non-compliance of internal auditor in preparing annual work plan before the year \\
11 & Non-compliance in appointment of secretary to the Board \\
12 & Non-compliance in legal advisor's role \\
13 & Non-compliance with Articles of Association of the company \\
14 & Non- compliance with Executive Regulation \\
Source: Adapted from Capital Market Authority (2011-2019).
\end{tabular}


regulatory tax compliance (Musimenta et al., 2019) validate the results of the present study on current companies' compliance on listed companies. So far, only the United Arab Emirates (UAE), Kingdom of Saudi Arabia (KSA) and Bahrain have rolled out VAT schemes among the Gulf Cooperation Council member countries - though those initiatives are still in the implementation stage. Non-compliance on the VAT system in Saudi Arabia attempted to reduce penalties by adopting a set of electronic applications and strictly overseeing the compliance by officials (Ershaid and Nawash, 2021). Non-compliance with VAT regulations can hinder the countries progress in general. To offset tax evasion in the country, the government imposes a criminal penalty with the levy in the form of output tax. Likewise, new business startups were also showing non-compliance with VAT regulations, which were also imposed three times the normal tax rates with criminal penalty were inflicted after a particular date of registration. If the offense continues by any company will make the penalty even double. Consequently, VAT compliance is considered one of the most substantial reforms of any country's public financial system (Shakkour et al., 2021).

The above results and discussion on current companies' compliance with value-added tax compliance on listed companies in Oman have revealed that it is important for every organization to implement both internal and external regulatory compliance both efficiently and in a timely manner in order to reduce the risk of disciplinary actions such as fines, penalties, and civil and criminal liabilities. The details on Table 1, Table 2 and Table 3 above have displayed the importance of the evolving role of compliance auditors in connection with listed companies in Oman. The recently introduced VAT in Oman will increase the regulatory compliance of listed companies. Thus, the findings of the research are consistent with and substantiate the evolving role of the compliance officer in the listed companies at MSX in Oman. Further, both current companies' compliance on listed companies and value-added tax compliance on listed companies in Oman will strengthen the evolving role of compliance officers among listed companies at MSX in Oman.

The study proposes that in the future, the proficiency in accounting concepts can facilitate organizations by adopting information communication technology enabled accounting practice.

\section{Implications}

The evolving role of a full-time compliance officer has significant implications for both the economy and the prospects of business growth. The results of the current study acknowledge the value of full-time compliance officers and compliance audits. Moreover, the findings can aid both in the appraisal of VAT accounting, compliance audit research and in the selection of proper assessment methods and criteria. The appointment of a compliance officer and compliance audit guarantees long term value creation among listed companies in Oman.

Notably, compliance audits guarantee adherence to the organization's regulatory rules, regulations, and guidelines prescribed by the government. It also ensures effective compliance with the organization's internal rules, policies, and processes. As a result of a compliance audit, trust among stakeholders may increase if they believe that the organization is operating within a legal framework. Further, it enables companies to meet timely submission of tax returns as per tax laws.

Therefore, this study may influence the management or board of directors to deal with applicable internal and external regulations in a more professional manner. This could enable an organisation to satisfy the interests of its shareholders, management, the government, and other stakeholders. In addition, this research may aid the policymakers, statutory regulators, Muscat Stock Exchange, and Capital Market Authority in designing thoughtful policies/ guidelines to appoint compulsory full-time compliance officer in all the listed companies in Oman. 
PAP

25,1

96

\section{Conclusion}

The study found out that there is a lack of timely compliance by companies in the existing law and these companies may face several pressures for compliance with VAT enforcement in Oman. Therefore, to comply with the disclosure requirements of listed companies, there is a growing need to appoint a full-time compliance officer with compliance audit.

For the compliance of a company to be achieved, managers or board of directors are obligated to follow applicable laws, regulations and rules depending on the nature of the organization and the relevant regulatory disclosures. The corporations should consider compliance regulations related to safety, direct or indirect tax laws, reporting guidelines of financial statements, securities contract, regulation act, contract act, prevention of money laundering act, special economic zones act, state employment laws, corporate social responsibilities, environmental laws, minimum wages act, foreign exchange regulations act, and public health regulations.

A compliance officer should take measures to adhere to all the above-mentioned applicable rules, regulations, and laws; including the laws of national or international government and various legislative aspects of a company.

This study recommends that future studies should employ quantitative research methods such as case studies on independent variables to better investigate VAT compliance among listed companies in Oman. Besides, the researchers could examine numerous other challenges that listed companies face in their attempt to employ a full-time compliance officer.

\section{References}

Arena, C., Liong, R. and Vourvachis, P. (2018), "Carrot or stick: CSR disclosures by Southeast Asian companies", Sustainability Accounting, Management and Policy Journal, Vol. 9 No. 4, pp. $422-454$.

Baalouch, F., Ayadi, S.D. and Hussainey, K. (2019), "A study of the determinants of environmental disclosure quality: evidence from French listed companies”, Journal of Management and Governance, Vol. 23 No. 4, pp. 939-971.

Capital Market Authority (2011-2019), Annual reports 2011 to 2019, Capital Market Authority, Sultanate of Oman.

Chang, Y.T., Chen, H., Cheng, R.K. and Chi, W. (2019), "The impact of internal audit attributes on the effectiveness of internal control over operations and compliance", Journal of Contemporary Accounting and Economics, Vol. 15 No. 1, pp. 1-19.

Ershaid, D. and Nawash, O. (2021), "The attitudes of VAT taxpayers toward the use of E-tax systems and their impact on tax compliance: a field study of Tabuk Region", Journal of Contemporary Issues in Business and Government, Vol. 27 No. 1, pp. 1-19.

Farrar, J., Kaplan, S.E. and Thorne, L. (2019), "The effect of interactional fairness and detection on taxpayers' compliance intentions", Journal of Business Ethics, Vol. 154 No. 1, pp. 167-180.

Fiandrino, S., Busso, D. and Vrontis, D. (2019), "Sustainable responsible conduct beyond the boundaries of compliance: Lessons from Italian listed food and beverage companies", British Food Journal, Vol. 121 No. 5, pp. 1035-1049.

Maglio, R., Rey, A., Agliata, F. and Lombardi, R. (2020), "Exploring sustainable governance: compliance with the Italian related party transactions regulation for the legal protection of minority shareholders", Corporate Social Responsibility and Environmental Management, Vol. 27 No. 1, pp. 272-282.

Majerowska, E. and Spigarska, E. (2021), "Influence of selected internal factors on the outputs of the financial-sector companies traded on the Warsaw Stock Exchange", Eurasian Economic Perspectives, Vol. 16 No. 1, pp. 193-204.

Meissner, M.H. (2018), "Accountability of senior compliance management for compliance failures in a credit institution”, Journal of Financial Crime, Vol. 25 No. 1, pp. 131-139. 
Mgammal, M.H., Bardai, B. and Ismail, K.N.I.K. (2018), "Corporate governance and tax disclosure phenomenon in the Malaysian listed companies", Corporate Governance: The International Journal of Business in Society, Vol. 18 No. 5, pp. 779-808.

Musimenta, D., Naigaga, S., Bananuka, J. and Najjuma, M.S. (2019), "Tax compliance of financial services firms: a developing economy perspective", Journal of Money Laundering Control, Vol. 22 No. 1, pp. 14-31.

Nalukenge, I., Nkundabanyanga, S.K. and Ntayi, J.M. (2018), “Corporate governance, ethics, internal controls and compliance with IFRS", Journal of Financial Reporting and Accounting, Vol. 16 No. 4, pp. 764-786.

Nowland, J., Chapple, L. and Johnston, J. (2020), "The role of the company secretary in facilitating board effectiveness: reporting and compliance", Accounting and Finance, Vol. 61 No. S1, pp. 1425-1456.

Pastory, P. (2019), "Inter-governmental relations and procurement non-compliance in African local government systems: insights from Tanzania”, Journal of Public Procurement, Vol. 19 No. 4, pp. 277-294.

Saenz, C. and Brown, H. (2018), "The disclosure of anticorruption aspects in companies of the construction sector: main companies worldwide and in Latin America”, Journal of Cleaner Production, Vol. 196 No. 1, pp. 259-272.

Sarea, A., Suharto, U., Hawaldar, I.T., Ibrahim, A. and Shaikh, Z.H. (2020), "Web-based financial reporting disclosure by Islamic banks in Oman: level of compliance", Journal of Investment Compliance, Vol. 21 No. 2/3, pp. 77-83.

Sentanu, I.N.W. and Budiartha, K. (2019), "Effect of taxation modernization on tax compliance", International Research Journal of Management, IT and Social Sciences, Vol. 6 No. 4, pp. 207-213.

Shakkour, A., Almohtaseb, A., Matahen, R. and Sahkkour, N. (2021), "Factors influencing the value added tax compliance in small and medium enterprises in Jordan", Management Science Letters, Vol. 11 No. 4, pp. 1317-1330.

Suleiman, H.A. and Sani, A.B. (2021), "IFRS 4 Disclosure and firm performance of insurance companies in Nigeria”, Asian Journal of Economics, Business and Accounting, Vol. 21 No. 6, pp. 27-38.

Suleiman, S. (2021), "Effect of foreign involvement on corporate tax noncompliance", Journal of Economics and Sustainability, Vol. 3 No. 1, pp. 23-32.

Tarmidi, D. (2019), "Tax compliance and uncompliance entity: a comparative study of investor reaction", International Journal of Academic Research in Accounting, Finance and Management Sciences, Vol. 9 No. 1, pp. 105-110.

Tawiah, V. and Boolaky, P. (2019), "Determinants of IFRS compliance in Africa: analysis of stakeholder attributes", International Journal of Accounting and Information Management, Vol. 27 No. 4, pp. 573-599.

Thottoli, M.M. (2021), "The relevance of compliance audit on companies' compliance with disclosure guidelines of financial statements", Journal of Investment Compliance, Vol. 22 No. 2, pp. 137-150.

Umar, M.A. and Masud, A. (2020), "Why information technology is constrained in tackling tax noncompliance in developing countries: Nigerian tax administrators' perspectives", Accounting Research Journal, Vol. 33 No. 2, pp. 307-322.

Usnick, L., Usnick, R., Usnick, W. and Usnick, S. (2018), "Managing compliance functions: centralize, decentralize, or hybridize?”, Southern Law Journal, Vol. 28 No. 2, pp. 201-214.

Van Wyk, J. and Rudman, R. (2019), "COBIT 5 compliance: best practices cognitive computing risk assessment and control checklist", Meditari Accountancy Research, Vol. 27 No. 5, pp. 761-788.

Venturelli, A., Caputo, F., Leopizzi, R. and Pizzi, S. (2019), "The state of art of corporate social disclosure before the introduction of non-financial reporting directive: a cross country analysis", Social Responsibility Journal, Vol. 15 No. 4, pp. 409-423. 
PAP

25,1

98
Ye, B. and Xiang, X. (2020), "Intergovernmental transfers and tax noncompliance", International Tax and Public Finance, Vol. 27 No. 2, pp. 312-338.

Zerban, A.M. and Madani, A.M.A. (2018), "Corporate governance and Board of Directors responsibility in appointing senior managers: a case in Saudi Arabia", International Journal of Business and Management, Vol. 13 No.1, pp. 183-189.

\section{About the author}

Mohammed Muneerali Thottoli is a qualified Company Secretary from The Institute of Company Secretaries of India, CA-Inter from The Institute of Chartered Accountants of India, Master of Commerce at Madras University, India, and has submitted his Ph.D. thesis (Impact of Information Communication Technology on Auditing Practices of accounting professionals in Kerala) in Bharathiar University. He is a Lecturer in the accounting department at the University of Nizwa, Oman since 2013, and has published extensively on accounting, auditing, ERP, and entrepreneurship in Asian countries. Mohammed Muneerali Thottoli can be contacted at: muneerali@unizwa.edu.om

For instructions on how to order reprints of this article, please visit our website: 